\title{
Tinjauan Normatif Pembela Hak Asasi Manusia dalam Hukum Internasional dan Hukum Nasional
}

\author{
Ryan Abraham Silalahi \\ ryanabrahamsilalahi@gmail.com \\ Universitas Katolik Soegijapranata \\ Jl. Pawiyatan Luhur Sel. IV No.1, Bendan Duwur, Kec. Gajahmungkur, Kota Semarang
}

\begin{abstract}
Human rights are acknowledgment that every human being has basic freedom and dignity. With this recognition, everyone has the right to defend and fight for their rights for their existence as a human being. Human Rights Defenders (HRDs) are everyone who works to defend and fight for people's human rights. In international law the rights of Human Rights Defenders are specifically manifested in the 1998 UN Declaration of Human Rights Defenders. Human rights and the extent to which Indonesia provides regulations for these human rights defenders. This study aims to analyze the protection of human rights defenders in the perspective of international law and the application of international law in national legal regulations related to the protection of human rights defenders. This research will use a qualitative normative juridical approach, with analytical descriptive research specifications and data collection techniques through literature study.
\end{abstract}

Keywords: Human Rights Defenders, International Law, National Law

\begin{abstract}
ABSTRAK: Hak asasi manusia merupakan pengakuan bahwa setiap manusia mempunyai kebebasan dasar dan martabat. Dengan pengakuan ini maka setiap orang memiliki hak untuk mempertahankan dan memperjuangkan hak-haknya demi eksistensinya sebagai manusia. Pembela Hak Asasi Manusia (Pembela HAM) merupakan setiap orang yang bekerja untuk mempertahankan dan memperjuangkan HAM.Dalam hukum internasional hak Pembela HAM dimanifestasikan secara khusus dalam Deklarasi Pembela HAM PBB tahun 1998. Berdasarkan itu, penting untuk melihat lebih lanjut bagaimana hukum internasional mengatur Pembela HAM dan bagaimana hukum Indonesia mengakomodir pelindungan terhadap Pembela HAM ini. Penelitian ini bertujuan untuk menganalisis pelindungan terhadap Pembela HAM dalam perspektif hukum Internasional dan penerapan hukum internasional dalam peraturan hukum nasional terkait pelindungan Pembela HAM. Penelitian ini akan menggunakan metode pendekatan yuridis normatif yang bersifat kualitatif, dengan spesifikasi penelitian deskriptif analitis dan teknik pengumpulan data melalui studi kepustakaan.
\end{abstract}

Kata Kunci: Pembela HAM, Hukum Internasional, Hukum Nasional 
JURNAL HUKUM POLITIK DAN KEKUASAAN

ISSN: 2722-970X (media online) Vol. 1 | No. 2 | Februari 2021

\section{PENDAHULUAN}

Hak Asasi Manusia (HAM) merupakan hak-hak yang melekat pada manusia secara alamiah, bukan diberikan oleh negara, melainkan dilindungi dan ditegakkan oleh negara. Mengingat HAM melekat pada manusia, maka dengan sendirinya setiap orang memiliki hak untuk memperoleh dan mempertahankan hak-haknya sebagai manusia. Maka dari itu hak-hak untuk mempertahankan hak nya sebagai manusia juga bukan diberikan oleh negara, melainkan timbul sebagai konsekuensi dari adanya HAM. Dalam konteks HAM, negara lah yang mempunyai kewajiban utama untuk meghormati, melindungi, dan memenuhi HAM. Namun, negara pula yang seringkali menjadi aktor utama pelanggaran HAM, baik dengan tindakan aktif (by commission) maupun pembiaran dengan tidak melakukan kewajiban hukum (by omission).

Melihat tindakan negara yang cenderung tidak mengindahkan prinsip-prinsip HAM, sejatinya menggugah orang-orang untuk melakukan upaya-upaya pemajuan dan perlindungan HAM baik secara individu maupun kelompok, yang mana orang-orang ini disebut juga Pembela Hak Asasi Manusia / Human Rights Defender (Pembela HAM). Pembela HAM memegang peran penting dalam upaya pelindungan dan pemajuan HAM bersamaan dengan semakin luasnya cakupan HAM serta semakin bervariasinya bentuk bentuk pelanggaran HAM. ${ }^{1}$ Dengan memegang peran penting dalam pemajuan dan pelindungan HAM, Pembela HAM juga kerap kali dalam posisi yang sangat rentan. Kerja-kerja kemanusiaan yang dilakukan oleh Pembela HAM banyak mendapatkan hambatan, ancaman, dan kekerasan, baik secara psikis, fisik, maupun berupa pembatasan-pembatasan tertentu seperti pembatasan kemerdekaan berekspresi dan kemerdekaan berorganisasi. $^{2}$

Sebagai contoh, yaitu dibunuhnya Munir dalam penerbangan ke Belanda yang diduga dibunuh karena pekerjaannya sebagai Pembela HAM. ${ }^{3}$ Pada tahun 2018, ditangkapnya Robertus Robet, karena diduga melakukan penghinaan terhadap Tentara Nasional Indonesia dalam orasinya di Aksi Kamisan. ${ }^{4}$ Selain itu, ditangkapnya Dandhy Laksono, yang mana diduga menyebarkan kebencian berdasarkan SARA melalu media elektronik terkait kasus Papua. ${ }^{5}$ Tak berhenti disitu, Veronica Coman seorang Pengacara HAM juga disurati polisi untuk dilakukan pemeriksaan atas

\footnotetext{
${ }^{1}$ Al Araf, M.Ali Syafaat, Peongky Indarti, 2005, Perlindungan terhadap Pembela Hak Asasi Manusia, Jakarta: IMPARSIAL, hal.4

${ }^{2}$ Ibid, hal.15

${ }^{3}$ Matra News, "Munir, Mengapa Dia Dibungkam?",https://matranews.id/munir-mengapa-dia-dibungkam/, diunduh pada tanggal 24 Juni 2019

4 Luthfia Ayu Azanella, "Kronologi Penangkapan Aktivis HAM Robertus Robet", https://nasional.kompas.com/read/2019/03/07/11592831/kronologi-penangkapan-aktivis-ham-robertusrobet, diunduh pada tanggal 13 April 2020

${ }_{5}$ Ambaranie Nadia Komala Avanita, "Dandhy dan Ananda Badudu Ditangkap Polisi, Ini Penyebabnya", https://nasional.kompas.com/read/2019/09/27/09540341/dandhy-dan-ananda-badudu-ditangkap-polisi-inipenyebabnya?page=all, diunduh pada tanggal 25 Januari 2020
}

http://journal.unika.ac.id/index.php/jhpk $\mid 100$ 
JURNAL HUKUM POLITIK DAN KEKUASAAN

ISSN: 2722-970X (media online) Vol. 1 | No. 2 | Februari 2021

dugaan tindakan provokasi atas insiden asrama mahasiswa Papua pada 4 September 2019.6 Maka dari itu, berdasarkan fakta-fakta diatas, dalam upaya perlindungan dan pemajuan HAM, hak-hak Pembela HAM ini harus dilindungi secara hukum.

Dalam perspektif internasional, Pembela HAM nyatanya sudah diatur secara tegas dan spesifik dalam Declaration On The Right And Responsibility Of Individuals, Groups And Organs Of Society To Promote And Protect Universally Recognized Human Rights And Fundamental Freedoms. Deklarasi ini juga sering disebut dengan Deklarasi Pembela HAM. Deklarasi ini mengatur hak-hak Pembela HAM dalam menjalankan aktivitasnya yang juga merupakan makna penting dari ketaatan terhadap tujuan dan prinsip Piagam Perserikatan Bangsa-Bangsa (PBB) dalam rangka kemajuan dan pelindungan semua hak asasi manusia dan kebebasan dasar bagi semua orang di seluruh negara di dunia. Deklarasi Pembela HAM ini merupakan bentuk implementasi nyata dari hukum internasional dalam menjamin hak hak Pembela HAM.

Indonesia sebagai negara anggota PBB sudah layak dan sepantasnya untuk memperhatikan dan mengimplementasikan prinsip prinsip yang tertuang dalam Deklarasi Pembela HAM. Berdasarkan hal tersebut, perlu kiranya untuk meneliti bagaimana hukum internasional mengatur Pembela HAM, serta bagaimana penerapannya ke dalam peraturan hukum nasional, yang harapannya dapat menjadi landasan pembaharuan hukum mengenai Pembela HAM.

\section{PEMBAHASAN}

\section{Pembela HAM dalam Perspektif Hukum Internasional}

Dalam perspektif hukum internasional, pemajuan dan penegakan HAM, bukan hanya berbicara mengenai peran negara. Deklarasi Pembela HAM PBB tahun 1998 (selanjutnya disebut dengan Deklarasi Pembela HAM) merupakan bentuk dari pengakuan hukum internasional terhadap setiap individu, kelompok, melakukan aktivitas-aktivitas atau kerja-kerja dalam rangka pemajuan dan penegakan HAM.?

Deklarasi Pembela HAM berisi pernyataan pernyataan umum mengenai pengakuan ataupun hak-hak dari Pembela HAM namun tidak mencantumkan mekanisme atau cara bagaimana deklarasi tersebut dapat diratifikasi. Maka dari itu, Deklarasi Pembela HAM tahun

6 CNN Indonesia, "Kronologi Kasus Veronica Koman Hingga Masuk Daftar Buron", https://www.cnnindonesia.com/nasional/20190920125617-12-432232/kronologi-kasus-veronica-komanhingga-masuk-daftar-buron, diakses pada tanggal 25 Januari 2020

${ }^{7}$ Majelis Umum Perserikatan Bangsa-Bangsa, "Deklarasi Pembela Hak Asasi Manusia", https://www.ohchr.org/Documents/Issues/Defenders/Declaration/declarationBahasa.pdf, diunduh 25 Maret 2020. 
JURNAL HUKUM POLITIK DAN KEKUASAAN

ISSN: 2722-970X (media online) Vol. 1 | No. 2 | Februari 2021

1998 merupakan soft law. ${ }^{8}$ Yang artinya, tidak mengikat secara hukum (legally binding), namun mengikat secara moral (morally binding). Negara negara anggota PBB tidak terikat secara hukum dalam Deklarasi Pembela HAM 1998 ini.

Walaupun tidak mengikat secara hukum, bukan berarti keberadaan soft law merupakan hal yang sia-sia. Soft law juga merupakan instrumen penting dalam pembaharuan hukum. Dengan adanya soft law, negara negara sebenarnya dapat menjadikannya sebagai pedoman dalam membuat suatu peraturan perundang-undangan, tanpa perlu mekanisme-mekanisme yang rumit. ${ }^{9}$ Dengan adanya soft law, menurut penulis, warga negara dapat mengetahui mengenai komitmen suatu negara terhadap suatu permasalahan, karena pemberlakuan soft law tergantung pada kemauan negara tersebut.

Pembela HAM dalam aktivitasnya melakukan pemajuan dan penegakan HAM tentu mempunyai hak hak yang melekat pada dirinya. Negara harus hadir dalam menjamin dilindungi nya hak hak tersebut. Sejatinya, dengan diakuinya hak hak tersebut, dapat meminimalisir tindakan ancaman, intimidasi, represif yang kerap dialami oleh Pembela HAM dalam aktivitas pembelaannya.

Menurut Hina Jilani dalam Rahayu, Pembela HAM memiliki aktivitas utama yang terbagi dalam beberapa ciri, yaitu ${ }^{10}$

All human rights for all ( HAM untuk semua), Human Rights everywhere (HAM dimanamana), Local, national, regional and international action (para Pembela HAM dapat bekerja pada level lokal, nasional, maupun internasional), Collecting and dissementing information on violations (melakukan investigasi dan mengumpulkan informasi tentang pelanggaran HAM), Supporting victims of human rights violations (membantu korban pelanggaran HAM), Action to secure accountability and to end impunity (menuntut pertanggungjawaban dan mengakhiri impunitas), Supporting better governance and government policy (mendorong kebijakan pemerintahan yang lebih baik), Contributing to the implementation of human rights treaties (kontribusi terhadap implementasi perjanjian HAM), Human Rights education and training (pendidikan dan pelatihan HAM).

Melihat berbagai aktivitas yang dilakukan oleh Pembela HAM, selanjutnya akan timbul pertanyaan, bagaimana standar minimum atau kualifikasi seseorang dapat disebut sebagai Pembela HAM? Menurut Fact Sheet No. 29, Human Rights Defenders: Protecting the Right to

\footnotetext{
${ }^{8}$ Marsudi Triadmodjo, 1998, "Peran Dan Fungsi "Soft Law" Dalam Perkembangan Hukum Internasional tentang Hak Asasi Manusia Dan Lingkungan Hidup", Mimbar Hukum 1998 VIII(31), hal. 45

${ }^{9} \mathrm{Ibid}$

${ }^{10}$ Rahayu, "Urgensi Perlindungan Hukum bagi Pembela Hak Asasi Manusia (Human Rights Defender) di Indonesia, Masalah Masalah Hukum, Vol. 39 no.2 (2010)
} 
JURNAL HUKUM POLITIK DAN KEKUASAAN

ISSN: 2722-970X (media online) Vol. 1 | No. 2 | Februari 2021

Defend Human Rights oleh PBB (selanjutnya disebut Fact Sheet PBB No.29), terdapat standar minimum untuk menentukan Pembela HAM, yaitu"11

a. Accepting the universality of human rights:

Human rights defenders must accept the universality of human rights as defined in the Universal Declaration of Human Rights.4 A person cannot deny some human rights and yet claim to be a human rights defender because he or she is an advocate for others. For example, it would not be acceptable to defend the human rights of men but to deny that women have equal rights.

Berdasarkan penjelasan diatas, dapat dimengerti bahwa seseorang dapat disebut sebagai Pembela HAM apabila menerima keuniversalitas HAM yang diatur dalam Universal Declaration of Human Rights ( selanjutnya disebut UDHR), dalam artian, seseorang tersebut tidak dapat dikatakan sebagai Pembela HAM apabila memperjuangkan suatu aspek HAM namun menolak beberapa aspek HAM lain dalam UDHR.

b. Who is right and who is wrong-does it make a difference? A second important issue concerns the validity of the arguments being presented. It is not essential for a human rights defender to be correct in his or her arguments in order to be a genuine defender. The critical test is whether or not the person is defending a human right. For example, a group of defenders may advocate for the right of a rural community to own the land they have lived on and farmed for several generations. They may conduct protests against private economic interests that claim to own all of the land in the area. They may or may not be correct about who owns the land. However, whether or not they are legally correct is not relevant in determining whether they are genuine human rights defenders. The key issue is whether or not their concerns fall within the scope of human rights. This is a very important issue because, in many countries, human rights defenders are often perceived by the State, or even the public, as being in the wrong because they are seen as supporting one side of an argument. They are then told that they are not "real" human rights defenders. Similarly, defenders who act in defence of the rights of political prisoners or persons from armed opposition groups are often described by State authorities as being supporters of such parties or groups, simply because they defend the rights of the people concerned. This is incorrect. Human rights defenders must be defined and accepted according to the rights they are defending and according to their own right to do so

11 United Nations, "Human Rights Defenders: Protecting the Right to Defend Human Rights", https://www.ohchr.org/Documents/Publications/FactSheet29en.pdf, hal.9, diunduhpada tanggal 25 Maret 2020 
JURNAL HUKUM POLITIK DAN KEKUASAAN

ISSN: 2722-970X (media online) Vol. 1 | No. 2 | Februari 2021

Berdasarkan penjelasan diatas, dapat dimengerti bahwa, seorang Pembela HAM terlepas dari dikotomi benar atau salah menurut hukum dalam aktivitas pembelaan HAM nya. Dalam artian, selama lingkup pembelaan tersebut dalam lingkup HAM, terlepas dari yang dibela adalah sesuatu yang salah atau benar, seseorang tersebut tetap disebut sebagai Pembela HAM.

c. Finally, the actions taken by human rights defenders must be peaceful in order to comply with the Declaration on human rights defenders.

Berdasarkan penjelasan diatas, dapat dimengerti bahwa aktivitas pembelaan yang dilakukan oleh Pembela HAM harus dilakukan dengan cara yang damai sesuai dengan Deklarasi Pembela HAM.

Maka dari itu, berdasarkan Fact Sheet PBB No.29, dapat dipahami bahwa standar minimum Pembela HAM adalah seseorang tersebut harus menerima HAM secara universal tidak mengesampingkan aspek HAM yang lain, tidak memperdulikan salah atau benarnya terhadap suatu kasus, yang paling penting adalah aktivitas yang mereka lakukan adalah aktivitas HAM, dan dilakukan secara damai.

Seperti yang sudah dijelaskan diatas, bahwasannya yang mempunyai tanggung jawab utama dalam penegakan dan pemajuan HAM adalah negara. Maka dari itu, dalam kaitannya dengan implementasi Deklarasi Pembela HAM oleh negara, Penulis mengambil contoh negaranegara di Uni Eropa. Uni-Eropa telah menjawab keberlakuan Deklarasi Pembela HAM yang merupakan soft law tersebut. Uni-Eropa tidak hanya menerima Deklarasi Pembela HAM 1998 tersebut secara moral, tetapi juga secara nyata membuat produk hukum spesifik mengenai Pembela HAM, yaitu Panduan Uni Eropa mengenai Pembela Hak Asasi Manusia tahun 2004 (selanjutnya disebut dengan Panduan UE mengenai Pembela HAM).

\section{Panduan Uni Eropa mengenai Pembela Hak Asasi Manusia tahun 2004}

Pengimplementasian Deklarasi Pembela HAM untuk pembaharuan hukum sudah diterapkan di Uni Eropa. Uni Eropa menerima dan mengembangkan Deklarasi Pembela HAM ini dengan bentuk nyata, yaitu dengan dibuatnya Panduan Uni Eropa mengenai Pembela Hak Asasi Manusia Tahun 2004. Panduan ini menyatakan dengan tegas bahwa Uni Eropa mendukung prinsip-prinsip yang terkandung di dalam Deklarasi Pembela HAM secara universal. ${ }^{12}$ Meskipun tanggung jawab utama dalam memajukan dan melindungi hak asasi manusia ada pada negara, Uni Eropa mengakui bahwa individu, kelompok, dan badan masyarakat seluruhnya memainkan peranan penting dalam memperjuangkan masalah hak asasi manusia. ${ }^{13}$ Dalam panduan ini juga mengatur klasifikasi mengenai kerja-kerja yang dilakukan oleh Pembela HAM. Selanjutnya, Panduan UE

${ }^{12} \mathrm{Al}$ Araf, op.cit, hal.112

${ }^{13}$ Ibid 
JURNAL HUKUM POLITIK DAN KEKUASAAN

ISSN: 2722-970X (media online) Vol. 1 | No. 2 | Februari 2021

mengenai Pembela HAM juga berisi mengenai bagaimana aturan pelaksanaan dari panduan ini. Dengan adanya aturan pelaksanaan ini, memperlihatkan bahwa Uni Eropa tidak hanya menerima Deklarasi Pembela HAM secara normatif namun juga terdapat komitmen yang tinggi untuk melaksanakan secara efektif prinsip-prinsip yang tercantum dalam Deklarasi Pembela HAM.

\section{Hak-Hak Pembela HAM}

Dalam melakukan aktivitas pembelaan HAM, tentu terdapat hak-hak yang dimiliki oleh Pembela HAM untuk menunjang aktivitasnya tersebut. Secara umum, hak-hak Pembela HAM dalam hukum internasional dapat ditemukan dalam Deklarasi Universal HAM dan Kovenan Hak-hak Sipil dan Politik. Namun, secara khusus hak-hak Pembela HAM diatur dalam Deklarasi Pembela HAM. Hak-hak tersebut adalah:

a. Hak Kebebasan Berpendapat

Kebebasan berpendapat yang penulis maksud bukan dalam konteks HAM pada umumnya. Terminologi hak kebebasan berpendapat dalam konteks Pembela HAM adalah sebuah hak yang digunakan untuk menunjang aktivitas pembelaan HAM. dalam Deklarasi Pembela HAM ini, kebebasann berpendapat tidak hanya diartikan pada hak seseorang tersebut untuk berpendapat, namun dinyatakan juga bahwa untuk menarik perhatian masyarakat. Dalam Pasal 8 ayat 2 Deklarasi Pembela HAM ini menegaskan bahwa ${ }^{14}$

Ini mencakup, antara lain, secara sendiri-sendiri maupun bersama-sama, hak untuk mengajukan kepada badan-badan pemerintah dan perwakilan atau organisasi yang bersangkutan dengan urusan-urusan publik, kritik dan usul guna memperbaiki fungsi mereka dan untuk menarik perhatian pada setiap aspek dari pekerjaan mereka yang dapat menghalangi atau mengganggu pemajuan, perlindungan dan pelaksanaan hak asasi manusia dan kebebasan dasar.

Berdasarkan pasal diatas dapat disimpulkan bahwa, Pembela HAM berhak melakukan kritik dan menarik perhatian pada setiap aspek pemerintahan yang berpotensi menghalangi pemajuan, perlindungan, dan pelaksanaan HAM.

b). Hak berpartisipasi aktif dalam urusan-urusan pemerintahan dan publik.

Dalam Deklarasi Pembela HAM, hak untuk berpartisipasi aktif dalam urusan pemerintahan dan publik tidak hanya mengatur soal hak setiap orang untuk berpartisipasi atau berada dalam pemerintahan atas dasar persamaan, namun juga menegaskan bahwa setiap orang harus mendapatkan akses secara efektif dan non-diskriminatif dalam kaitannya berpartisipasi dalam pemerintahan dan melaksanakan urusan urusan publik, dan juga mengatur mengenai partisipasi dalam sudut pandang lain yaitu dalam bentuk kritik dan usulan berdasarkan prinsip-prinsip HAM dan kebebasan dasar bagi pemerintah untuk memperbaiki fungsi mereka

\footnotetext{
${ }^{14}$ Majelis Umum Perserikatan Bangsa-Bangsa, loc.cit
} 
JURNAL HUKUM POLITIK DAN KEKUASAAN

ISSN: 2722-970X (media online) Vol. 1| No. 2 | Februari 2021

dan untuk memerhatikan segala aspek dalam pemerintahan yang dapat mengganggu pemajuan, perlindungan, dan pelaksanaan HAM dan kebebasan dasar. (Pasal 8 Deklarasi Pembela HAM)

c) Hak untuk mendapatkan pemulihan dan pelindungan hukum.

Dalam Deklarasi Pembela HAM secara tegas dan lebih spesifik mengatur mengenai hak untuk mendapatkan pemulihan dan pelindungan. Deklarasi Pembela HAM mengatur mengenai adanya hak atas pemulihan efektif dan pelindungan hukum serta peran negara dalam melindungi hak-hak tersebut. Di Deklarasi Pembela HAM ini juga menyatakan bahwa setiap orang berhak untuk mendapat perlindungan efektif di bawah undang-undang nasional dalam rangka bereaksi terhadap atau menentang, lewat cara-cara damai, kegiatan dan tindakan, termasuk kelalaian oleh negara. (Pasal 9 dan Pasal 12 ayat 2 Deklarasi Pembela HAM)

Dengan adanya pasal ini sejatinya aktivitas yang dilakukan oleh Pembela HAM, yang sering kali karena berkaitan dengan "kelalaian negara", seharusnya dapat diakomodir secara baik dalam kerangka hukum, agar potensi kriminalisasi yang kerap dialami oleh Pembela HAM dapat diminimalisir. Berdasarkan pasal diatas juga dapat dilihat bahwasannya Deklarasi Pembela HAM mengamanatkan setiap negara untuk melakukan perlindungan hukum secara efektif terhadap Pembela HAM dibawah undang-undang nasional untuk menunjang aktivitas pembelaannya.

d) Hak untuk pemajuan dan penegakan HAM

Dalam Deklarasi Pembela HAM, hak untuk pemajuan dan penegakan HAM secara tegas diatur dalam Pasal 1, yang menyatakan bahwa setiap orang mempunyai hak, secara sendirisendiri maupun bersama-sama, untuk memajukan dan memperjuangkan perlindungan dan pemenuhan hak asasi manusia dan kebebasan dasar di tingkat nasional dan internasional. ${ }^{15}$ Selain itu Pembela HAM juga mempunyai hak untuk membentuk organisasi non pemerintah, mengajukan pengaduan tentang kebijakan dan tindakan pejabat dan badan-badan pemerintahan berkenaan dengan pelanggaran hak asasi manusia dan kebebasan dasar lewat petisi atau sarana lain yang patut kepada badan-badan judisial, administratif atau legislatif yang berwenang di dalam negeri atau kepada otoritas lain yang kompeten yang ditetapkan oleh sistem hukum suatu negara, untuk mengumpulkan, menerima dan menggunakan sumber daya dengan maksud yang jelas guna memajukan dan melindungi hak asasi manusia dan kebebasan dasar lewat jalan damai. ${ }^{16}$ ( Pasal 5, Pasal 9, Pasal 13 Deklarasi Pembela HAM)

\footnotetext{
${ }^{15}$ Majelis Umum Perserikatan Bangsa-Bangsa, loc.cit

${ }^{16}$ Majelis Umum Perserikatan Bangsa-Bangsa, loc.cit
} 
JURNAL HUKUM POLITIK DAN KEKUASAAN

ISSN: 2722-970X (media online) Vol. 1 | No. 2 | Februari 2021

\section{Pembela HAM dalam Hukum Nasional}

Dalam produk hukum nasional Indonesia, belum ada peraturan yang secara khusus dan spesifik mengenai Pembela HAM. Namun, dalam kaitannya dengan hak yang dapat dikategorikan sebagai Pembela HAM, hal ini dapat dilihat dari tindakan Indonesia sebagai negara anggota PBB, meratifikasi International Covenant on Civil and Political Rights, yang berbentuk Undang-Undang Republik Indonesia Nomor 12 Tahun 2005 tentang Pengesahan International Covenant On Civil And Political Rights(Kovenan Internasional Tentang Hak-Hak Sipil Dan Politik). Namun berkaitan dengan Pembela HAM, tindakan ratifikasi International Covenant on Civil and Political Rights belumlah memadai, karena masih merupakan aturan umum yang intinya mengatur bahwasannya setiap manusia berhak menikmati HAM, namun tidak tercantum bagaimana hak dari seseorang tersebut untuk memperjuangkan hak asasinya sebagaimana diatur dalam Deklarasi Pembela HAM. Melihat fakta ini, mempertegas bahwa Indonesia tidak menjalankan amanat dari Deklarasi Pembela HAM yang mengharuskan negara untuk melindungi Pembela HAM secara efektif.

Dalam hukum internasional, hak kebebasan berpendapat, hak untuk berpartisipasi aktif di urusan-urusan pemerintahan dan publik, hak mendapatkan pemulihan dan pelindungan hukum, dan hak untuk pemajuan dan penegakan HAM sebenarnya sudah tertera dalam Deklarasi Universal HAM, Kovenan Hak-hak Sipil dan Politik, dan instrument HAM lainnya. Namun, yang membedakan, antara Deklarasi Pembela HAM dan instrumen HAM yang lain adalah hak-hak yang tertera dalam Deklarasi Pembela HAM merupakan konsep khusus dari mekanisme pembelaan HAM. Maka dari itu, penting untuk mengimplementasikan prinsip-prinsip Deklarasi Pembela HAM secara tegas dan spesifik dalam hukum nasional, demi pelindungan terhadap praktek pembelaan HAM. Maka, akibat dari tidak diimplementasikannya Deklarasi Pembela HAM secara tegas dan efektif dalam hukum nasional Indonesia, kerja-kerja yang dilakukan oleh Pembela HAM kerap kali mengalami intimidasi, represif, ancaman, dan lain sebagainya. Hak-hak Pembela HAM masih dianggap secara umum, padahal dalam hukum internasional eksistensi Pembela HAM diatur secara khusus.

Peraturan hukum nasional Indonesia yang berbicara mengenai Pembela HAM hanya dapat ditemui dalam Peraturan Komisi Nasional Hak Asasi Manusia mengenai Nomor 5 Tahun 2015 tentang Prosedur Perlindungan terhadap Pembela HAM (selanjutnya disebut Peraturan KOMNAS HAM).

Dalam Pasal 1 ayat 2 Peraturan KOMNAS HAM ini menyatakan bahwa hak-hak Pembela HAM adalah serangkaian hak asasi manusia yang diatur dalam hukum nasional dan internasional mengenai hak asasi manusia yang telah diterima oleh Negara Republik Indonesia untuk menunjang kerja-kerja pemajuan dan perlindungan hak asasi manusia. Menurut penulis terjadi keambiguitasan di Peraturan KOMNAS HAM ini. Peraturan KOMNAS HAM ini menyamakan HAM pada umumnya dengan hak pembelaan HAM. 
JURNAL HUKUM POLITIK DAN KEKUASAAN

ISSN: 2722-970X (media online) Vol. 1 | No. 2 | Februari 2021

Yang mana, menurut penulis harus dibedakan antara HAM dengan hak pembelaan HAM. Hak pembelaan HAM digunakan untuk menunjang terpenuhinya HAM. Deklarasi Pembela HAM mengakui bahwasannya terdapat hak dan tanggung jawab individu, kelompok, dan perkumpulan untuk memajukan penghormatan dan memperkuat pengetahuan mengenai hak asasi manusia dan kebebasan dasar di tingkat nasional dan internasional. ${ }^{17}$

Deklarasi Pembela HAM mengatur mengenai hak untuk memajukan penghormatan dan memperkuat HAM, yang mana hal tersebut tentu beda dengan HAM pada umumnya. HAM pada umumnya mengakui bahwasannya seseorang tersebut mempunyai HAM, namun tidak menyatakan bagaimana hak seseorang tersebut memperjuangkan HAM nya,

Sehingga, apabila HAM dan hak Pembela HAM disamakan seperti yang diatur dalam Peraturan KOMNAS HAM ini, sejatinya sama sekali belum mengatur mengenai bagaimana penghormatan dan penegakan HAM dapat ditunjang. Maka dari itu belum jelas apa saja hak-hak Pembela HAM dalam konteks Peraturan KOMNAS HAM ini. Dengan tidak jelas dan tidak spesifiknya hak-hak Pembela HAM diatur dalam Peraturan KOMNAS HAM ini, sejatinya menimbulkan tanda tanya, sebenarnya pelanggaran hak Pembela HAM yang dimaksud dalam Peraturan KOMNAS HAM ini hak yang seperti apa.

Dalam Pasal 1 ayat 4 Peraturan KOMNAS HAM ini menyatakan bahwasannya perlindungan adalah serangkaian tindakan yang dilakukan oleh KOMNAS HAM, dengan atau tanpa bekerja sama dengan instansi lainnya, dengan maksud uuntuk memberikan perlindungan kepada Pembela HAM yang dilanggar hak-haknya, baik oleh Individu, kelompok masyarakat, institusi swasta maupun negara. Apabila hak-hak Pembela HAM tidak diatur secara tegas, jelas, dan spesifik, maka tidak ada tolak ukur dalam hal bagaimana hak-hak Pembela HAM itu dilanggar, sehingga perlindungan Pembela HAM pun menjadi ambigu.

Selanjutnya, mengenai kualifikasi Pembela HAM, dalam Pasal 5 Peraturan KOMNAS HAM ini menyatakan bahwa Komnas HAM memberikan perlindungan kepada Pembela HAM yang memenuhi kualifikasi sebagai berikut:

a) Terbukti melakukan kerja-kerja pemajuan dan perlindungan hak asasi manusia dengan cara-cara damai.

b) Memiliki kerentanan atas serangan atau pelanggaran hak akibat dari kerja-kerja pemajuan dan perlindungan hak asasi manusia.

c) Menerima universalitas hak asasi manusia.

Berdasarkan hal diatas, dapat penulis simpulkan bahwasannya kualifikasi Pembela HAM tersebut sesuai dengan Fact Sheet PBB No.29. Yang mana pada intinya menegaskan bahwasannya standar minimum Pembela HAM adalah bahwa Pembela HAM tersebut melakukan

\footnotetext{
${ }^{17}$ Majelis Umum Perserikatan Bangsa-bangsa. loc.cit
} 
JURNAL HUKUM POLITIK DAN KEKUASAAN

ISSN: 2722-970X (media online) Vol. 1| No. 2 | Februari 2021

aktivitas pembelaannya dengan damai serta menerima universalitas hak asasi manusia, yakni dengan menerima semua HAM yang ada tanpa menolak HAM lainnya. ${ }^{18}$ Namun, apabila berdasarkan Fact Sheet PBB No.29, terdapat satu poin standar minimum yang tidak diatur dalam Peraturan KOMNAS HAM ini, yaitu mengenai terbebas dari dikotomi benar atau salah, yang artinya selama lingkup pembelaan tersebut dalam lingkup pembelaan HAM, terlepas dari yang dibela adalah sesuatu yang salah atau benar, seseorang tersebut tetap disebut sebagai Pembela HAM. ${ }^{19}$

Menurut Fact Sheet PBB No.29, poin tersebut merupakan hal yang penting, karena di beberapa negara Pembela HAM sering dipersepsikan oleh negara, bahkan oleh masyarakat, melakukan kesalahan karena argumennya mendukung salah satu pihak. Menurut Fact Sheet PBB No.29 ini seharusnya terlepas dari benar atau salahnya yang Pembela HAM tersebut bela, selama aktivitasnya ada dalam cakupan HAM, maka ia tetap disebut sebagai Pembela HAM. ${ }^{20}$

Peraturan KOMNAS HAM ini lebih mengatur mengenai mekanisme kerja KOMNAS HAM, bukan pengakuan konkrit terhadap eksistensi Pembela HAM. Peraturan ini bukan mengakui dan mengatur bagaimana hak dan aktivitas Pembela HAM. Akan lebih efektif apabila terdapat Undang-Undang atau Peraturan Perundang-undangan yang lebih tinggi, yang mengatur secara tegas dan jelas mengenai pelindungan terhadap Pembela HAM.

\section{KESIMPULAN}

Hukum internasional mengatur secara khusus mengenai hak untuk membela HAM atau yang biasa disebut sebagai hak Pembela HAM. Pelindungan hukum terhadap Pembela HAM dalam perspektif hukum internasional diatur dalam Deklarasi Pembela HAM tahun 1998 yang berbentuk soft law, yaitu tidak mempunyai kekuatan hukum yang mengikat, namun mengikat secara moral. Berdasarkan Deklarasi Pembela HAM dapat dipahami bahwa Pembela HAM mempunyai beberapa hak, yakni hak kebebasan berpendapat, hak untuk berpartisipasi aktif dalam urusan urusan pemerintahan dan publik, hak untuk mendapatkan pemulihan dan pelindungan hukum, serta hak untuk pemajuan dan penegakan HAM. Selanjutnya,kendati pun Deklarasi Pembela HAM PBB tahun 1998 tidak mempunyai kekuatan hukum yang mengikat, namun negara-negara Uni Eropa mengakui, melaksanakan serta mengembangkan Deklarasi tersebut sebagai pedoman dengan dibuatnya Panduan Uni Eropa mengenai Pembela HAM tahun 2004 .

Peraturan hukum nasional terkait pelindungan Pembela HAM masih diatur secara umum. Namun, terdapat aturan yang sejatinya mengakui eksistensi Pembela HAM, yaitu Peraturan

${ }^{18}$ United Nations, loc.cit

${ }^{19}$ Ibid

${ }^{20}$ Ibid 
JURNAL HUKUM POLITIK DAN KEKUASAAN

ISSN: 2722-970X (media online) Vol. 1| No. 2 | Februari 2021

Komisi Nasional Hak Asasi Manusia mengenai Nomor 5 Tahun 2015 tentang Prosedur Perlindungan terhadap Pembela HAM. Namun perlindungan dalam Peraturan KOMNAS HAM tersebut tidak efektif serta banyak hal dalam substansi Peraturan KOMNAS HAM yang tidak sesuai dengan Deklarasi Pembela HAM.

\section{SARAN}

1. Bahwa dalam rangka pelindungan hukum terhadap Pembela HAM secara spesifik, dalam konteks hukum nasional Indonesia, seharusnya diatur dalam Undang-Undang sebagaimana diamanatkan oleh Deklarasi Pembela HAM.

2. Mendorong Pemerintah Indonesia untuk segera mengimplementasi prinsip-prinsip HAM dan kebebasan dasar yang diatur dalam Deklarasi Pembela HAM ke dalam produk hukum nasional secara tegas, jelas, dan spesifik.

\section{DAFTAR PUSTAKA}

Araf, Al, Syafaat, M.Ali, Indarti, Peongky, 2005, Perlindungan terhadap Pembela Hak Asasi Manusia, Jakarta: IMPARSIAL

Azanella, Luthfia Ayu, 2019, Kronologi Penangkapan Aktivis HAM Robertus Robert, https://nasional.kompas.com/read/2019/03/07/11592831/kronologi-penangkapan-aktivisham-robertus-robet

CNN Indonesia, 2019, Kronologi Kasus Veronica Koman Hingga Masuk Daftar Buron, https://www.cnnindonesia.com/nasional/20190920125617-12-432232/kronologi-kasusveronica-koman-hingga-masuk-daftar-buron,

Declaration On The Right And Responsibility Of Individuals, Groups And Organs Of Society To Promote And Protect Universally Recognized Human Rights And Fundamental Freedoms tahun 1998 / Deklarasi Pembela Hak Asasi Manusia (https://www.ohchr.org/Documents/Issues/Defenders/Declaration/declarationBahasa.p df)

Matra Indonesia, 2019, Munir, Mengapa Dia Dibungkam?, https://matranews.id/munir-mengapadia-dibungkam/

Peraturan Komisi Nasional Hak Asasi Manusia Nomor 5 Tahun 2015 tentang Prosedur Perlindungan terhadap Pembela HAM (https://www.komnasham.go.id/files/1508480535peraturan-komnas-ham-no-5-tahun-\$\$FIJYA.pdf) 
JURNAL HUKUM POLITIK DAN KEKUASAAN

ISSN: 2722-970X (media online) Vol. 1| No. 2 | Februari 2021

Rahayu, 2010, Urgensi Perlindungan Hukum bagi Pembela Hak Asasi Manusia (Human Rights Defender) di Indonesia. Masalah-Masalah Hukum, 39. https://ejournal.undip.ac.id/index.php/mmh/article/view/11576/9744

Triadmojo, M. 1998. Peran dan Fungsi "Soft Law" Dalam Perkembangan Hukum Internasional tentang Hak Asasi Manusia dan Lingkungan Hidup. Mimbar Hukum, 45. Di unduh dari http://i-lib.ugm.ac.id/jurnal/detail.php?datald=1959

United Nations, 2004, Human Rights Defenders: Protecting the Right to Defend Human Rights, https://www.ohchr.org/Documents/Publications/FactSheet2gen.pdf 